А.О. Кучерявий, доктор педагогічних наук, доцент, НУОУ імені Івана Черняховського

\title{
ТЕХНОЛОГІЯ ПРОЕКТУВАННЯ ДИСТАНЦІЙНИХ НАВЧАЛЬНИХ КУРСІВ У ВІЙСЬКОВІЙ ОСВІТІ
}

Окремими складовими технологї проектування дистанційних курсів є чотири етапи. На етапі створення програми дистанційного навчального курсу визначаються його загальні иүілі, теми, цілі вивчення окремих тем та їх зміст. Етап структурування курсу за модулями передбачає визначення окремих змістових складників, які вимагають окремого послідовного опрацювання. На етапі визначення навчальних завдань до кожного модуля враховуються психологічні особливості прочесу засвоєння навчального матеріалу. Етап розробки вимог до методичного забезпечення модулів дистанційного навчального курсу зумовлений необхідністю урахування особливостей вивчення навчального матеріалу саме в процесі дистаниійного навчання.

Ключові слова: дистанційне навчання; навчальний курс; проектування; технологія; етапи; модуль.

Постановка проблеми. Елементи дистанційного навчання стають все більш затребуваними в процесі підготовки фахівців у вищій школі. 3 часом набувають вони поширення й у військовій освіті. Зокрема, цього вимагає Стратегічний оборонний бюлетень України, затверджений Указом Президента України від 6 червня 2016 року № 240/2016. На вимогу цього документа в Національному університеті оборони України імені Івана Черняховського створено Науковий центр дистанційного навчання, що є дуже важливою та значущою подією, адже створення дистанційних курсів $є$ багатоаспектним заходом, в якому беруть участь педагоги, інженери, дизайнери та інші фахівці. Водночас в педагогічній науці не визначено роль та функції кожного 3 них, відповідно системно не вивчені й усі окремі складові зазначеного процесу. Отже, наявною є проблема недосконалості теоретичних засад розробки дистанційних курсів не лише в аспекті ऑiі організації, а й реалізації окремих етапів. Вивченню одного 3 них, етапу проектування дистанційного навчального курсу (далі - курсу), й присвячене це дослідження. Саме на етапі проектування відбувається теоретична розробка курсу, на підставі якої в подальшому створюватиметься навчальний продукт науково-педагогічними працівниками та іншими фахівцями.

Аналіз останніх досліджень і публікацій. В останні десятиріччя науковцями накопичено значний обсяг наукової, методичної та навчальної літератури 3 різних питань дистанційного навчання, зокрема низка публікацій та видань присвячена саме проектуванню дистанційних курсів [15]. Серед зазначених та інших літературних джерел найбільш повно, на нашу думку, питання проектування дистанційних курсів розглянуто в навчальному посібнику за редакцією В.Ю. Бикова та В.М. Кухаренка [5]. Зокрема, в ньому розкриваються питання визначення цілей курсу, психологічні підходи до навчання (біхевіоризм, когнітивний підхід, конструктивізм), йдеться про структуру дистанційного курсу (“Передмова", “Автори курсу”, “Тьютор”, "Новини курсу”, “Програма курсу”, “Головна сторінка тижневого заняття”) та визначаються вимоги до нього. Проте ні в цій роботі, ні в інших не йдеться 
про врахування в процесі проектування дистанційного курсу психологічних особливостей засвоєння навчального матеріалу, що буде зроблено в нашому дослідження при побудові відповідної технології проектування.

Метою статті $\epsilon$ визначення технологічних засад проектування дистанційних навчальних курсів. Відповідними завданнями дослідження $є$ структурування технології проектування дистанційних навчальних курсів за етапами та визначення їх сутності й особливостей.

Виклад основного матеріалу. Як зазначалося вище, проектування дистанційного навчального курсу є невід'ємним елементом його створення. Результатом цього процесу має стати проект курсу, що складається з низки матеріалів, в яких містяться відповіді на запитання щодо: а) призначення курсу; б) цільової аудиторії споживачів курсу; в) цілей навчання; г) загального змісту навчання; г) послідовності вивчення навчального матеріалу; д) навчальних завдань, які має виконати користувач курсу при опрацюванні кожної з тем; е) методичних умов дистанційного навчання.

Тобто проект курсу має дати відповіді на всі запитання його розробникам перед створенням навчального продукту.

На нашу думку, ті матеріали, що утворюють проект дистанційного навчального курсу та відповідають на зазначені вище запитання, можуть бути представлені його навчальною програмою, структурною схемою вивчення курсу, сукупністю навчальних завдань та методичними вимогами до організації роботи $з$ дистанційним курсом його користувача.

Зважаючи на визначені складові проекту дистанційного курсу, вважаємо, що його створення можливо технологізувати, при цьому етапами відповідної технології виступатимуть:

- створення програми курсу;

- структурування курсу за модулями;

- визначення навчальних завдань до кожного модулю;

- розробка вимог до методичного забезпечення модулів курсу.

Розглянемо особливості кожного з етапів.

Дистанційний навчальний курс, так само як і традиційний навчальний курс, повинен грунтуватися на навчальній програмі курсу. Зауважимо, що підходи до створення цієї програми можуть дещо різнитися в залежності від статусу та призначення дистанційного курсу, адже він може бути або самостійним навчальним курсом, тобто основним, або складником загального (аудиторного) навчального курсу, тобто допоміжним. Від призначення курсу залежать цілі вивчення окремих тем: якщо він основний, знання і уміння визначаються в навчальній програмі як кінцевий результат опанування навчальним матеріалом, а якщо допоміжний - цілями вивчення теми може бути первинне ознайомлення 3 навчальною інформацією, формування понять, елементарних умінь тощо.

Відзначимо деякі особливості створення навчальної програми саме для дистанційного курсу. Перша з них стосується визначення його цілей, адже вони зумовлюються не лише призначенням курсу, а й умовами його вивчення. За нашим спостереженням за практикою використання таких 
курсів, рівень сформованості знань та умінь засобами дистанційного навчання, як правило, не перевищує аналогічні результати, здобуті в ході традиційного аудиторного навчання. Це пояснюється специфікою засвоєння змісту окремих навчальних дисциплін, яке має відбуватися в спеціалізованих лабораторіях, із застосуванням спеціального обладнання, у ході виконання групових вправ або вправ за безпосередньої присутності інструктора (викладача). Тому формулювання конкретних знань та умінь, здобутих за результатами дистанційного навчання, має бути коректним 3 огляду на реалістичність їх досягнення. Наприклад, формулювання цілі як “знати норму наказу” виглядає цілком коректним, оскільки слухач (курсант) дійсно здатний іiі засвоїти, працюючи за комп'ютером. Водночас, така ціль, як "уміти застосовувати норму наказу" виглядає не завжди коректною. Лише, якщо навчальний процес у його дистанційному форматі допускає відтворення ситуацій практичної діяльності військовослужбовця, мета щодо формування такого вміння виглядає виправданою. Відповідними прикладами можуть служити тактичні уміння щодо планування та прогнозування певних процесів і ситуацій, уміння працювати з мапами, документацією тощо. В інших випадках може йтися про формальний бік уміння, яке формується в умовах, коли фабула практичної ситуації подається хіба що абстрактно. Наприклад, сумнівною буде якість уміння, сформованого засобами лише дистанційного навчання, щодо управління військовою технікою, військовим підрозділом, використання засобів самозахисту та ін. У низці випадків коректним формулюванням практико-зорієнтованої цілі дистанційного курсу буде, наприклад, “вміти застосовувати норму наказу при розгляді теоретичних задач" або “вміти використовувати норму наказу при моделюванні певних ситуацій”. Остаточне формування деяких умінь може бути предметом подальшого навчання, навчальної практики чи стажування, тому в програмі дистанційного курсу відповідні цілі можуть зумовлювати сформованість умінь на певному рівні - первинному, елементарному, початковому, репродуктивному та ін., що забезпечить коректність їх визначення.

Сукупність визначених цілей дистанційного навчального курсу $\epsilon$ підставою для розробки його змісту, який складається з окремих тем, а також розподілу загальних цілей курсу між цими темами. Зауважимо, що формування змісту дистанційного курсу також має свої особливості. Відомо, що при підготовці навчального курсу для аудиторного вивчення зміст навчальної програми не ставиться у відповідність до кількості годин, відведених на його вивчення, або кредитів. Але при цьому викладачі, спираючись на свій досвід, формують зміст курсу такого обсягу, який реально опрацювати на навчальних заняттях та у ході самостійної роботи, адже ці види навчальної діяльності слухачів і курсантів регламентуються часом та мають календарні обмеження. Проблеми ж часу при вивченні курсу дистанційного навчання фактично відсутні, адже працювати 3 ним слухач (курсант) буде у зручний для себе час, стільки разів повертаючись до навчального матеріалу - скільки йому потрібно для забезпечення високої 
якості засвоєння. Отже, на відміну від аудиторного навчання зміст дистанційного курсу може бути визначений у будь-якому обсязі.

Таким чином, за результатами першого етапу технології проектування дистанційного курсу стають визначеними його цільові орієнтири та зміст, що дозволяє перейти до виконання другого етапу проектування структурування курсу за модулями навчання.

Під модулем дистанційного курсу ми розуміємо певну тему або іiі складову, яка потребує окремого опрацювання користувачем курсу з огляду на методику вивчення цієї теми. Отже, модуль дистанційного курсу уособлює його змістовий складник, а їх сукупність утворюють структуру курсу.

Архітектура дистанційного навчального курсу, як правило, передбачає послідовне вивчення його складових та допускає використання розгалуження. Саме розгалуження є доцільним у ситуаціях, що припускають обрання користувачем курсу певної траєкторії його опрацювання, або у ситуаціях, коли зміна траєкторії навчання зумовлюється якістю засвоєння курсу на проміжних етапах. Припустимо, що дистанційний курс за аналогією 3 аудиторним навчальним курсом не передбачає розгалуження i, відповідно, вивчення всіх тем та модулів відбуватиметься у лінійній послідовності. Тоді достатнім буде передбачити можливість повторного вивчення теми у разі, якщо вона не засвоєна на допустимому рівні якості. Це, в свою чергу, вимагає уведення до структури курсу модулів узагальнення навчального матеріалу та контролю навчальних досягнень користувачів курсу, що передбачатиме проведення діагностичних процедур з послідуючим наданням об'єкту навчання права вивчати наступну тему. У разі, якщо в ході вивчення курсу його користувач вважатиме, що він добре обізнаний у матеріалі поточної теми, він пропускатиме певні модулі в ії межах, зупиняючись лише на модулях узагальнення навчального матеріалу i контролю власних начальних досягнень.

Зауважимо, що якість засвоєння кожної теми стає визначальною рисою процесу опрацювання дистанційного курсу. Тому, на нашу думку, суб'єктом проектування курсу мають бути створені можливі умови для їі забезпечення, зокрема передбачення на початку вивчення кожної теми повторення попереднього навчального матеріалу, а, отже, введення до структури курсу відповідних модулів.

Наявність структури дистанційного курсу дозволяє реалізувати наступний етап проектування - визначення навчальних завдань в межах кожного модулю.

За нашим переконанням, розробка або добір навчальних завдань повинні відповідати не лише змісту певної теми, а й особливостям процесу засвоєння навчального матеріалу, який, в свою чергу, характеризується етапами чуттєвого сприйняття, розуміння, закріплення та застосування знань [6-8].

Розглянемо особливості розробки та добору навчальних завдань у їх проекції на етапи процесу засвоєння навчального матеріалу. 
Реалізація етапу чуттєвого сприйняття можлива в різний спосіб, але його висока якість може бути забезпеченою через одночасне залучення різних органів почуттів. Тому користувачеві доцільно запропонувати перегляд навчального уроку, навчального чи документального фільму, відео 3 конференції чи інтерв'ю відомих фахівців 3 проблематики поточної теми тощо. Завдання може стосуватися, зокрема, й самостійного спостереження за явищем або розвитком якоїсь ситуації, проведення лабораторного експерименту чи дослідження певної ситуації в службовій діяльності військовослужбовця. Підкреслимо, що яким би не було завдання, його дидактичною цінністю $є$ створення умов для найширшого залучення органів почуттів слухача (курсанта) під час першого ознайомлення 3 навчальним матеріалом.

Наступний етап засвоєння навчального матеріалу (його розуміння) реалізовуватиметься через добір навчальних завдань, які допоможуть користувачу курсу розібратися в особливостях змісту явищ, процесів, моделей, які вивчаються, тощо. Вочевидь, це завдання виконуватиметься під час того ж самого перегляду відеоуроку чи інших відео-, аудіо- або текстових матеріалів. Тобто реалізація перших двох етапів засвоєння навчального матеріалу відбуватиметься послідовно при опрацюванні одного об'єкта пізнавальної діяльності. Проте, якщо для реалізації першого етапу важливим було одночасне залучення різних органів почуттів, то для другого цілеспрямована розумова діяльність, спрямована на формування понять. Отже, важливим $є$ передбачення таких навчальних завдань, які забезпечать максимальну активність суб'єкта навчання в процесі пізнання. Засобом активізації розумової діяльності слухача (курсанта) може стати низка запитань, які примусять його звернути увагу на ті чи інші особливості навчального матеріалу, здійснити порівняння з раніше вивченими об'єктами тощо. Ці запитання можуть бути запропоновані користувачеві курсу як до опрацювання навчального матеріалу, так і після нього. Перший варіант, за нашим переконанням, є доцільним у разі, якщо повторне спостереження за об’єктом пізнання є неможливим. У такому випадку заздалегідь визначені запитання утворять необхідну цільову настанову на сприйняття. Другий варіант, ймовірно, вимагатиме повторного перегляду відеоуроку, прослуховування аудіоматеріалів тощо. Цілком можливим $є$ й комбінування обох варіантів: заздалегідь запропоновані запитання формують цільову настанову на сприйняття навчального матеріалу, а запитання, надані після знайомства 3 ним, призначені для уточнення правильності сприйняття, акцентування на необхідних нюансах тощо.

Доцільність визначення низки запитань залишається й на етапі закріплення навчального матеріалу, коли в користувача курсу вже сформувалося поняття. Результатом реалізації цього етапу $є$ сформоване знання. Проте група чергових запитань має іншу зорієнтованість та переслідує інші цілі. На поточному етапі засвоєння навчального матеріалу запитання мають спонукати користувача курсу до синтезу нової навчальної інформації з тим знанням, яке на цей час формує його світогляд. Такі 
запитання можуть мати проблемний характер, вимагати від суб’єкта навчання розумової роботи щодо аналізу, синтезу, порівняння та узагальнення інформації. Крім запитань користувачеві курсу доцільно визначати в якості завдань такі традиційні вправи, як опрацювання тексту зі складанням плану, тез чи конспекту, розв'язання теоретичних задач та ін. Має сприяти закріпленню нового знання і тестування, де тести передбачають не лише вибір правильної відповіді, а й укладання тверджень, доповнення визначень, встановлення правильного порядку виконання алгоритмів, пошук помилок тощо.

Реалізація останнього етапу засвоєння навчального матеріалу, формування в користувачів курсу певних умінь, можлива через розробку та добір таких завдань, виконання яких вимагає застосування отриманого знання в спеціально змодельованих навчальних умовах. Зауважимо, що суб'єкту дистанційного навчання можуть бути запропоновані завдання, які необхідно виконувати в навчальному середовищі самого електронного курсу, а також такі, що виконуються поза ним.

Отже, третій етап технології проектування дистанційного курсу завершується добором навчальних завдань, які дозволяють досягти цілей вивчення кожного з його модулів.

На останньому етапі технології проектування дистанційного курсу має відбуватися розробка вимог до методичного забезпечення модулів дистанційного курсу. 3 урахуванням специфіки навчальної дисципліни, іiі окремих тем та самих визначених модулів вимоги до методичного забезпечення можуть стосуватися обсягів теоретичного матеріалу, які $\epsilon$ обов'язковими для самостійного опрацювання користувачами курсу, ілюстрацій, мап, відео, алгоритмів та прикладів виконання практичних вправ, форм та строків звітності, засобів комунікації 3 керівником дистанційного навчання (викладачем) та ін.

Висновки (в т.ч. перспективи подалыших досліджень у даному напрямку). Таким чином, розробка дистанційного навчального курсу вимагає його попереднього проектування, яке, в свою чергу, може реалізуватися на технологічних засадах. Складовими (етапами) відповідної технології є створення програми курсу, його структурування за модулями, визначення навчальних завдань до кожного модулю та розробка вимог до методичного забезпечення модулів курсу. Здійснений опис технології проектування дистанційних курсів має допомогти їх розробникам на першому етапі створення цього навчального продукту. В подальшому нами передбачається встановлення складових технології розробки дистанційних курсів, упродовж якої відбуватиметься створення їх окремих елементів (відео-, аудіоматеріалів, слайдів, тестів тощо) відповідно до укладеного за визначеною вище технологією проекту курсу. 


\section{ЛІТЕРАТУРА}

1. Методичні вказівки до розробки дистанційних курсів в системі MOODLE / Харк. нац. ун-т міськ. госп-ва ім. О. М. Бекетова; уклад.: О. М. Анісімов, Б. П. Бочаров, М. Ю. Воєводіна. Х.: ХНУМГ, 2014. - $61 \mathrm{c}$.

2. Молчанюк B. A. Аналіз методологічних засад проектування дистанційних курсів / В. А. Молчанюк [Електронний ресурс]. http://nvd.luguniv.edu.ua/archiv/2015/N4\%2832\%29/6.PDF.

3. Буркіна Н. В. Проектування методичної системи дистанційного навчання математики у вищих навчальних закладах : дис. ... канд. пед. наук : 13.00.04 / Буркіна Наталя Валеріївна. Черкаси, 2009. - 244 с.

4. Педагогічні аспекти відкритого дистанційного навчання / О.О. Андрєєв, К.Л. Бугайчук, Н.О. Каліненко та ін.; За ред. О.О Андрєєва, В.М. Кухаренка - ХНАДУ, Харків: "Міськдрук", 2013. $-212 \mathrm{c}$.

5. Технологія створення дистанційного курсу: навчальний посібник / Биков В.Ю., Кухаренко В.М., Сиротинко Н.Г. та ін.; За ред. В.Ю. Бикова та В.М. Кухаренка - К.: Міленіум, 2008. - $324 \mathrm{c}$.

6. Дидактика средней школы: Некоторые проблемы современной дидактики: учеб. пособие / Под ред. М.Н. Скаткина. - 2-е изд., перераб. и доп. - М.: Просвещение, 1982. - 219 с.

7. Дидактика современной школы / Б.С. Кобзарь, Г.Ф. Кумарина, Ю.А. Кусый и др. - К.: Рад. шк., 1987. - 351 с.

8. Проектування самостійної роботи студентів юридичних спеціальностей : навч. посіб. / А.О. Кучерявий, М.Л. Шелухін, В.В. Кадала та ін.; За заг. редакцією А.О. Кучерявого. Донецьк : ПП “ВД “Кальміус”, 2013. - 200 с.

А.А. Кучерявый, доктор педагогических наук, доцент, НУОУ имени Ивана Черняховського

\section{ТЕХНОЛОГИЯ ПРОЕКТИРОВАНИЯ ДИСТАНЦИОННЫХ УЧЕБНЫХ КУРСОВ В ВОЕННОМ ОБРАЗОВАНИИ}

Отдельными составляющими технологии проектирования дистанционных курсов являются четыре этапа. На этапе создания программы дистанционного учебного курса определяются его общие цели, темы, цели изучения отдельных тем и их содержание. Этап структурирования курса по модулям предполагает определение отдельных содержательных составляюших, которые требуют отдельного последовательного изучения. На этапе определения учебных заданий к каждому модулю учитываются психологические особенности процесса усвоения учебного материала. Этап разработки требований к методическому обеспечению модулей дистанциионого учебного курса обусловлен необходимостью учета особенностей изучения учебного материала именно в процессе дистанционного обучения.

Ключевые слова: дистанционное обучение; учебный курс; проектирование; технология; етапь; модуль.

\section{A. Kucheriavyi, doctor of pedagogical sciences, associate professor, THE TECHNOLOGY OF PROJECTING DISTANCE LEARNING COURSES IN THE MILITARY EDUCATION}

The separate components of technology projecting of distance courses there are four stages. On the stage of creation the programs of distance learning course are determined its general aims, themes, which studies of separate themes, and its maintenance. The structuring stage of the course by modules envisages determinations separate components by contents that require successive working. Psychological peculiarities of the process of learning are taken into account at the stage of defining educational tasks for each module. The stage of development of requirements to the methodical providing of the on-line training course's modules is predefined by the necessity of taking into account of features of study of educational material exactly in the process of distance studies.

Key words: distance learning; training course; projecting; technology; stages; module. 